\title{
Efficient Route to Highly Water-Soluble Aromatic Cyclic Hydroxamic Acid Ligands
}

\author{
Michael Seitz ${ }^{[a]}$ and Kenneth N. Raymond ${ }^{*[a]}$
}

Keywords: O ligands / Ligand design / Aromatic substitution / Heterocycles

2-Hydroxyisoquinolin-1-one (1,2-HOIQO) is a new member of the important class of aromatic cyclic hydroxamic acid ligands which are widely used in metal sequestering applications and metal chelating therapy. The first general approach for the introduction of substituents at the aromatic ring of the chelating moiety is presented. As a useful derivative, the highly water-soluble sulfonic acid has been synthesized by an efficient route that allows general access to 1,2-HOQIO 3-carboxlic acid amides, which are the most relevant for applications.

(C) WILEY-VCH Verlag GmbH \& Co. KGaA, 69451 Weinheim, Germany, 2007) [a] Department of Chemistry, University of California and Lawrence Berkeley National Laboratory, Berkeley, CA 94720-1460 USA Fax: + 1 (510) 4865283

E-mail: raymond@socrates.berkeley.edu

\section{Introduction}

Hydroxypyridinones constitute a very important class of ligands for the complexation of hard Lewis-acidic metal ions. ${ }^{[1]}$ This motif occurs in nature, e.g. in the amino acid $L$-minosine ${ }^{[2]}$ or naturally occurring siderophores. ${ }^{[3]}$ In addition, these species have been utilized for a number of medicinal applications, such as chelation treatment of metal ion imbalances (e.g. $\operatorname{iron}^{[4]}$ or aluminum ${ }^{[1 \mathrm{a}],[5]}$ ). One of the three isomeric forms of hydroxypyridinone is 1hydroxypyridin-2-one (1,2-HOPO).

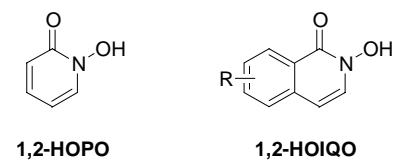

Figure 1. 1,2-HOIQO - A benzannulated analogue of 1,2-HOPO

Ligands of this type have a number of very attractive properties, such as facile synthetic access, high affinity / stability with a wide range of metal ions under physiological conditions, and useful photophysical properties. As a consequence, 1,2-HOPO has been widely used for the design of multidentate ligands for a number of applications, such as actinide sequestering, ${ }^{[6]}$ magnetic resonance imaging, ${ }^{[7]}$ treatment of iron-overload, ${ }^{[8]}$ and lanthanide luminescence. ${ }^{[9]}$ Despite these advantageous characteristics, 1,2HOPO ligand architectures often suffer from low aqueous solubility of the corresponding metal complexes. In other ligand systems (e.g. catechols or 8-hydroxyquinolines) this problem has been solved by sulfonation of aromatic scaffolds which usually increases the solubilty greatly. ${ }^{[10]}$ Unfortunately, the pyridinone scaffold is not easily amenable to the facile introduction of substitutents because most aromatic substitution reactions can not be used because of the instability of 1,2-HOPO under the harsh reaction conditions. To solve this problem, we recently introduced derivatives of 2-hydroxyisoquinolin-1-one (1,2-HOIQO) 3carboxylic acid (Figure 1), a benzanullated analogue of 1,2-
HOPO. ${ }^{[11]}$ Unlike hydroxypyridinones, a key precursor for the synthesis of 1,2-HOIQO can be modified by electrophilic aromatic substitution reactions, yielding, for example, the chlorosulfonated isocoumarin 1 (Scheme 1). In this communication we report the synthesis and functionalization of the corresponding sulfonated 1,2-HOIQO species, which has extremely high water-solubility.

\section{Results and Discussion}

The synthesis of the sulfonated 1,2-HOIQO ligand starts with the chlorosulfonated isocoumarin derivative $\mathbf{1}$ (Scheme 1). ${ }^{[11]}$

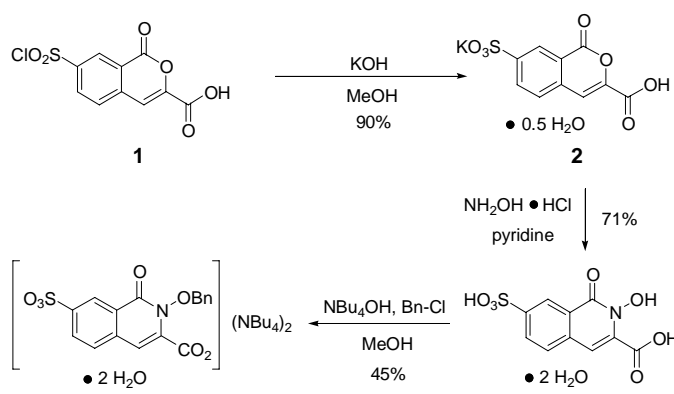

4

3

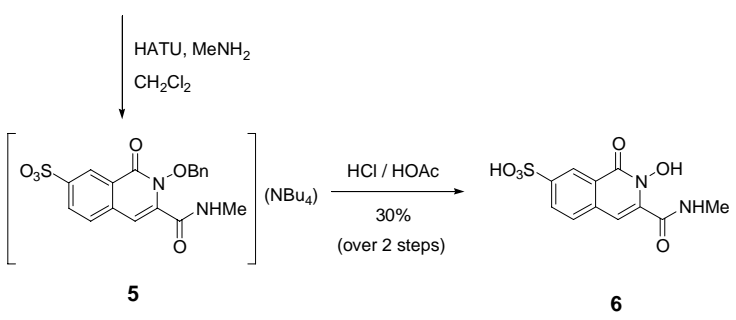

Scheme 1. Synthesis of sulfonated hydroxamic acid ligand 6.

Hydrolysis with methanolic $\mathrm{KOH}$ furnished the corresponding potassium sulfonate in good yield after recrystallization. Transformation to the 2-hydroxy-isoquinolin-1-one 2 with hydroxylamine hydrochloride in refluxing pyridine, followed by a simple workup procedure (filtration and ion exchange with a strongly acidic resin: Dowex $50 \mathrm{Wx} 2, \mathrm{H}^{+}$form) gave analytically pure hydroxamic acid derivative $\mathbf{3}$ as the dihydrate. The next step proved to be critical for the success of this synthetic route due to a 
number of challenges: $\mathbf{3}$ is only soluble in water, the dianion in $\mathbf{4}$ after benzyl protection can not be purified by strongly acidic ionexchange chromatography due to the lability of the protecting group under these conditions, and finally, the key intermediate 4 has to be soluble in organic solvents in order to enable further transformations such as amide coupling reactions. After a number of unsuccessful approaches, the best strategy for the protection reaction was found to be the use of tetrabutylammonium hydroxide / benzyl chloride in $\mathrm{MeOH}$ to yield the tetrabutylammonium salt $\mathbf{4}$, which is highly soluble in unpolar media (e.g. $\mathrm{CHCl}_{3}, \mathrm{CH}_{2} \mathrm{Cl}_{2}$, $\mathrm{CH}_{3} \mathrm{CN}$, EtOAc) and can be purified easily by column chromatography on silica. Carboxylate $\mathbf{4}$ can directly be coupled to methylamine under standard conditions using HATU to give the corresponding methyl amide 5 , which can again be purified by straightforward column chromatography on silica. Acidic benzyl deprotection followed by strongly acidic ion-exchange chromatography (Dowex 50Wx2, $\mathrm{H}^{+}$form) gives the final sulfonated ligand $\mathbf{6}$ in pure form.

To test whether the carboxylate in key intermediate $\mathbf{4}$ could also be activated in a different way, the corresponding acid chloride 7 was prepared under standard conditions (oxalyl chloride, cat. DMF) (Scheme 2). The resulting crude material is reasonably stable and shows high reactivity towards amines in preliminary experiments, e.g. reaction with $\mathrm{MeNH}_{2}$ yields an amide that is identical to $\mathbf{5}$ which was obtained by HATU coupling. The activated carboxylic acid $\mathbf{7}$ will be very useful in the future for less reactive amines (e.g. aromatic amines, secondary amines, etc.).

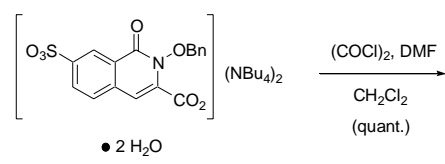

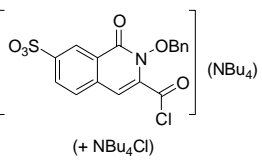

7
Scheme 2. Synthesis of the acid chloride 7.

Since 3 is the first molecule of this kind, characterization of the structure and regiochemistry of the 1,2-HOIQO derivative was performed. The 7-position for the sulfonic acid functionality, as well as the presence of the expected 1,2-HOIQO core, was confirmed through single crystal X-ray crystallography of the corresponding disodium salt (Figure 2). ${ }^{[12]}$ In addition, a $2 \mathrm{D}{ }^{1} \mathrm{H}$ NMR COSY experiment confirmed the major isomer in solution to be the one substituted in 7-position (Figure 3).

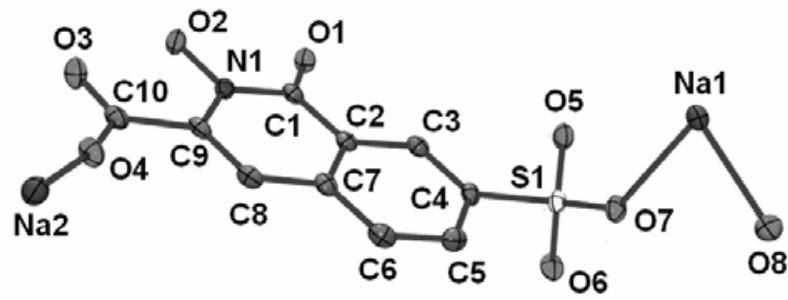

Figure 2. Asymmetric unit of the disodium salt monohydrate of 3 . Thermal ellipsoid plot (Ortep 3 for Windows, ${ }^{[13]} 50 \%$ probability level) with atom numbering scheme. Hydrogens are omitted for clarity.

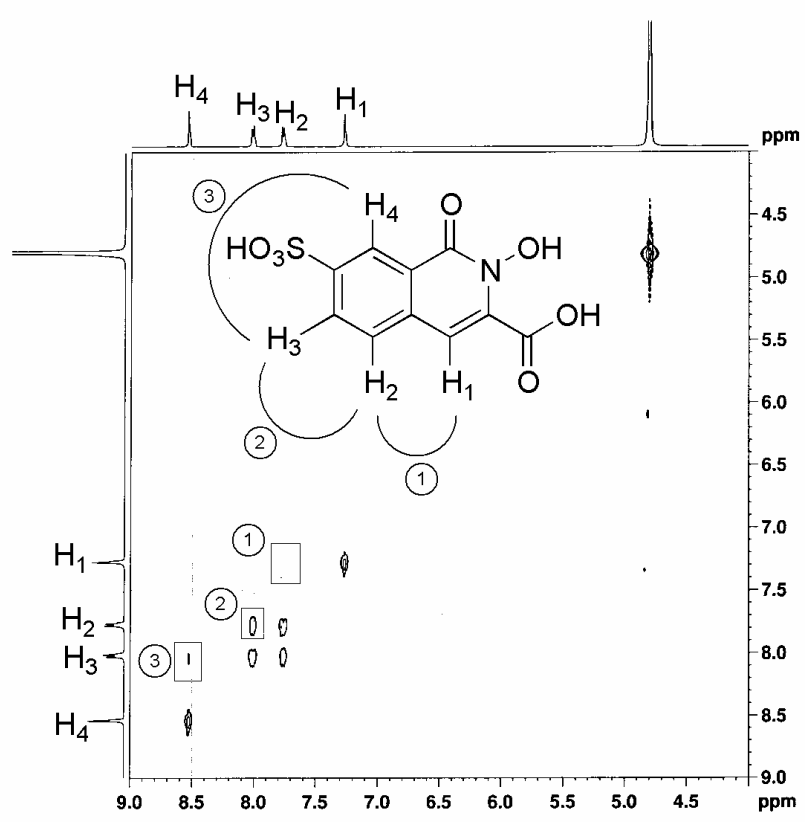

Figure 3. $2 \mathrm{D}{ }^{1} \mathrm{H}-\mathrm{NMR}\left(500 \mathrm{MHz}, \mathrm{D}_{2} \mathrm{O}, 20^{\circ} \mathrm{C}\right)$ of 3 - COSY: Aromatic region.

\section{Conclusions}

With the development of this synthetic route, access to sulfonated, highly water-soluble aromatic cyclic hydroxamic acid derivatives has been achieved for the first time. The key intermediates 4 and 7 , which can readily be coupled to amines under standard conditions, will especially be very useful for the preparation of new hydroxamate ligands, with potential applications in aqueous chelation. Investigations into the coordination chemistry of this ligand class are currently under way.

\section{Experimental Section}

Synthetic Procedures - General:

Chemicals were purchased from commercial suppliers and used as received unless stated otherwise. Solvents and $\mathrm{NEt}_{3}$ were dried by standard procedures (MeOH: $\mathrm{Mg} / \mathrm{I}_{2}, \mathrm{CH}_{2} \mathrm{Cl}_{2}$ and $\mathrm{NEt}_{3}: \mathrm{CaH}_{2}$ ). Pyridine was distilled before use. "Millipore water" used for ion-exchange chromatography refers to water obtained from a Millipore Milli-Q water purification system (resistivity: $18.2 \mathrm{M} \Omega^{*} \mathrm{~cm}^{-1} @ 25{ }^{\circ} \mathrm{C}$ ). Elemental analyses and mass spectrometry were performed by the microanalytical and mass spectrometry facilities of the University of California, Berkeley. NMR spectra were measured at $20^{\circ} \mathrm{C}$ on Bruker AVQ-400 $\left({ }^{1} \mathrm{H}: 400 \mathrm{MHz},{ }^{13} \mathrm{C}: 101 \mathrm{MHz}\right)$ and AV-500 ( $\left.{ }^{1} \mathrm{H}: 500 \mathrm{MHz}\right)$ spectrometers.

Potassium 3-carboxy-isocoumarin-5-sulfonate hemihydrate (2):

3-Carboxy-7-chlorosulfonyl-isocoumarin $(\mathbf{1})^{[11]}(313 \mathrm{mg}, 1.08 \mathrm{mmol}, 1.0$ equiv.) was suspended in $\mathrm{MeOH}(5 \mathrm{~mL})$. A solution of $\mathrm{KOH}(128 \mathrm{mg}, 2.28$ mmol, 2.1 equivs.) in $\mathrm{MeOH}(5 \mathrm{~mL})$ was added and the reaction was heated to reflux for $9 \mathrm{~h}$. After cooling down to ambient temperature, the solid was collected on a filter, washed with $\mathrm{MeOH}$, and air-dried. The crude product was dissolved in a minimum of water $(\mathrm{pH}=2, \mathrm{HCl}), \mathrm{KCl}(30 \mathrm{mg})$ was added, and the solution was stored at $0^{\circ} \mathrm{C}$ for 2 days. The precipitate was collected, washed with $\mathrm{MeOH}$ and dried in vacuo at $50^{\circ} \mathrm{C}$ overnight to yield an off-white solid (309 mg, 90\%).

M.p. $>200{ }^{\circ} \mathrm{C} .{ }^{1} \mathrm{H}-\mathrm{NMR}\left(400 \mathrm{MHz}, \mathrm{D}_{2} \mathrm{O}\right): \delta=8.47(\mathrm{~d}, J=1.8 \mathrm{~Hz}, 1 \mathrm{H})$, $8.11(\mathrm{dd}, J=8.2,1.8 \mathrm{~Hz}, 1 \mathrm{H}), 7.73(\mathrm{~d}, J=8.2 \mathrm{~Hz}, 1 \mathrm{H}), 7.46(\mathrm{~s}, 1 \mathrm{H}) \mathrm{ppm}$. 
${ }^{13} \mathrm{C}-\mathrm{NMR}\left(101 \mathrm{MHz}, \mathrm{D}_{2} \mathrm{O}\right): \delta=164.5,162.9,146.0,144.3,137.8,132.2$, $129.0,126.3,121.8,111.0 \mathrm{ppm}$. MS (ES-, MeOH): $\mathrm{m} / \mathrm{z}(\%)=283(50$, [M$\left.\left.\mathrm{K}+\mathrm{MeOH}-\mathrm{H}_{2} \mathrm{O}\right]^{-}\right), 269,\left(100,[\mathrm{M}-\mathrm{K}]^{-}\right)$. Anal. Calcd. for $\mathrm{C}_{10} \mathrm{H}_{5} \mathrm{KO}_{7} \mathrm{~S} \bullet 0.5$ $\mathrm{H}_{2} \mathrm{O}\left(M_{\mathrm{r}}=317.32\right): \mathrm{C}, 37.85 ; \mathrm{H}, 1.91$. Found: C, 37.46; H, 1.79.

\section{2-Hydroxy-3-carboxy-isoquinolin-1-one-7-sulfonic acid dihydrate (3):}

Potassium 3-carboxy-isocoumarin-7-sulfonate hemihydrate (2) $(300 \mathrm{mg}$, $973 \mu \mathrm{mol}, 1.0$ equiv.) was suspended in pyridine $(10 \mathrm{~mL})$. Hydroxylamine hydrochloride ( $81.1 \mathrm{mg}, 1.17 \mathrm{mmol}, 1.2$ equivs.) was added and the mixture was heated to $100^{\circ} \mathrm{C}$ (bath temperature) for $5.5 \mathrm{~h}$. After cooling down, the yellow solid was collected, washed with $\mathrm{MeOH}$, and air-dried to yield a light-yellow solid $(324 \mathrm{mg})$. This crude product was dissolved in $5 \mathrm{~mL}$ Millipore water $(5 \mathrm{~mL})$ and subjected to ion-exchange chromatography (Dowex 50Wx2-200, $\mathrm{H}^{+}$form, activated with $8 \mathrm{wt} \% \mathrm{H}_{2} \mathrm{SO}_{4}$ ). The fractions showing UV activity on a Merck silica TLC plate $\mathrm{F}_{254}\left(\lambda_{\text {ex }}=254 \mathrm{~nm}\right)$ were combined, concentrated, and dried under reduced pressure $(\mathrm{p} \approx 0.2 \mathrm{mbar}$, $\mathrm{T}_{\text {bath }}=35^{\circ} \mathrm{C}$ ). The product was obtained as the dihydrate in the form of a colorless solid (222 mg, 71\%).

M.p. $>200{ }^{\circ} \mathrm{C} .{ }^{1} \mathrm{H}-\mathrm{NMR}\left(400 \mathrm{MHz}, \mathrm{D}_{2} \mathrm{O}\right): \delta=8.48(\mathrm{~d}, J=1.5 \mathrm{~Hz}, 1 \mathrm{H})$, 7.97 (dd, $J=8.6,1.5 \mathrm{~Hz}, 1 \mathrm{H}), 7.72(\mathrm{~d}, J=8.6 \mathrm{~Hz}, 1 \mathrm{H}), 7.22(\mathrm{~s}, 1 \mathrm{H}) \mathrm{ppm}$. ${ }^{13} \mathrm{C}-\mathrm{NMR}\left(101 \mathrm{MHz}, \mathrm{D}_{2} \mathrm{O}\right): \delta=164.3,159.2,142.7,135.6,133.0,129.3$, $129.1,125.7,123.9,110.7$ ppm. MS (ES-): $\mathrm{m} / \mathrm{z}(\%)=239\left(9,[\mathrm{M}-\mathrm{COOH}]^{-}\right)$, 226.9 (9), $\left.141.4(100,[\mathrm{M}-2 \mathrm{H})]^{2-}\right)$. Anal. Calcd. for $\mathrm{C}_{10} \mathrm{H}_{7} \mathrm{NO}_{7} \mathrm{~S} \bullet 2 \mathrm{H}_{2} \mathrm{O}\left(M_{\mathrm{r}}\right.$ =321.26): C, 37.39; H, 3.45; N, 4.36; Found: C, 37.39; H, 3.39; N, 4.19.

\section{Protected carboxylate 4:}

2-Hydroxy-3-carboxy-isoquinolin-1-one-7-sulfonic acid dihydrate (3) (714 $\mathrm{mg}, 2.12 \mathrm{mmol}, 1.0$ equiv.) was dissolved in dry $\mathrm{MeOH}(30 \mathrm{~mL})$ and a solution of $\mathrm{Bu}_{4} \mathrm{NOH}(1 \mathrm{M}$ in $\mathrm{MeOH}, 6.67 \mathrm{~mL}$ solution, $6.67 \mathrm{mmol}, 3.0$ equivs.) was added dropwise, followed by $\mathrm{BnCl}$ (309 mg, $2.44 \mathrm{mmol}, 1.1$ equivs.). The yellow mixture was heated to reflux for $24 \mathrm{~h}$. After concentration of the solution in vacuo, the thick yellow oil was subjected to column chromatography $\left(\mathrm{SiO}_{2}\right.$, gradient: $\mathrm{CH}_{2} \mathrm{Cl}_{2} / \mathrm{MeOH} \quad 9: 1$ to $\mathrm{CH}_{2} \mathrm{Cl}_{2} / \mathrm{MeOH}$ 7:1). The fractions with $\mathrm{R}_{\mathrm{f}}=0.9$ (TLC: $\mathrm{SiO}_{2}$, $\mathrm{CH}_{2} \mathrm{Cl}_{2} / \mathrm{MeOH}$ 1:1, UV-detection) were collected, concentrated, and dried under reduced pressure at $50^{\circ} \mathrm{C}$ (bath temperature) for $12 \mathrm{~h}$. The pale yellow, oily product was obtained as the dihydrate $(890 \mathrm{mg}, 45 \%)$.

${ }^{1} \mathrm{H}-\mathrm{NMR}\left(400 \mathrm{MHz}, \mathrm{CDCl}_{3}\right): \delta=8.86(\mathrm{~d}, J=1.7 \mathrm{~Hz}, 1 \mathrm{H}), 8.14(\mathrm{dd}, J=$ 8.3, 1.7 Hz, $1 \mathrm{H}), 7.80-7.74(\mathrm{~m}, 2 \mathrm{H}), 7.46(\mathrm{~d}, J=8.3 \mathrm{~Hz}, 1 \mathrm{H}), 7.39-7.30$ (m, $3 \mathrm{H}), 6.57$ (s, $1 \mathrm{H}), 5.56(\mathrm{~s}, 2 \mathrm{H}), 3.23-3.09(\mathrm{~m}, 16 \mathrm{H}), 1.60-1.46(\mathrm{~m}, 16$ $\mathrm{H}), 1.40-1.23$ (m, $16 \mathrm{H}), 0.92(\mathrm{t}, J=7.3 \mathrm{~Hz}, 24 \mathrm{H}) \mathrm{ppm} .{ }^{13} \mathrm{C}-\mathrm{NMR}(101$ $\left.\mathrm{MHz}, \mathrm{CDCl}_{3}\right): \delta=165.0,158.8,145.4,144.5,137.6,135.4,130.4,130.1$, 128.4, 128.1, 126.0, 125.0, 124.8, 100.8, 78.2, 58.4, 23.7, 19.5, $13.6 \mathrm{ppm}$. MS (ES-): $\mathrm{m} / \mathrm{z}(\%)=615.3\left(25,\left[\mathrm{M}+\mathrm{NBu}_{4}\right]^{-}\right), 374.0(22,[\mathrm{M}+\mathrm{H}]), 283.3(33$ $\left.[\mathrm{M}+\mathrm{H}-\mathrm{Bn}]^{-}\right), 246.0\left(51,\left[\mathrm{M}-\mathrm{OBn}-\mathrm{CO}_{2}+\mathrm{Na}\right]^{-}\right), 223\left(100,\left[\mathrm{M}-\mathrm{OBn}-\mathrm{CO}_{2}\right]\right)$. Anal. Calcd. for $\mathrm{C}_{49} \mathrm{H}_{83} \mathrm{~N}_{3} \mathrm{O}_{7} \mathrm{~S} \bullet 2 \mathrm{H}_{2} \mathrm{O}\left(M_{\mathrm{r}}=894.30\right)$ : C, 65.81; H, 9.81; N, 4.70. Found: $\mathrm{C}, 65.41 ; \mathrm{H}, 10.24 ; \mathrm{N}, 4.64$.

\section{Protected methyl amide 5:}

Protected carboxylate 4 (610 mg, $682 \mu \mathrm{mol}, 1.0$ equiv.) was dissolved in dry $\mathrm{CH}_{2} \mathrm{Cl}_{2}(20 \mathrm{~mL})$ and HATU $(285 \mathrm{mg}, 750 \mu \mathrm{mol}, 1.1$ equivs.) was added. The mixture was stirred for $1 \mathrm{~h}$ before $\mathrm{MeNH}_{2}\left(40 \%\right.$ in $\left.\mathrm{H}_{2} \mathrm{O}, 2 \mathrm{~mL}\right)$ was added dropwise. Stirring was continued for $12 \mathrm{~h}$, the yellow solution was concentrated, and the residue was subjected to column chromatography $\left(\mathrm{SiO}_{2}\right.$, column length: $28 \mathrm{~cm}$, inner diameter $=1.3 \mathrm{~cm}, \mathrm{CH}_{2} \mathrm{Cl}_{2} / \mathrm{MeOH} 9: 1$ to $\mathrm{CH}_{2} \mathrm{Cl}_{2} / \mathrm{MeOH}$ 7:1). The fractions with $\mathrm{R}_{\mathrm{f}}=0.64$ (TLC: $\mathrm{SiO}_{2}$, $\mathrm{CH}_{2} \mathrm{Cl}_{2} / \mathrm{MeOH}$ 7:1, UV detection) were collected, concentrated, and dried under reduced pressure at $50^{\circ} \mathrm{C}$ (bath temperature) for $8 \mathrm{~h}$ to yield a colorless glassy solid $\left(292 \mathrm{mg}\right.$ ) that contained $\mathrm{NBu}_{4} \mathrm{PF}_{6}$ ( 0.34 equivs.). This material was used in the next step without further purification.

${ }^{1} \mathrm{H}-\mathrm{NMR}\left(400 \mathrm{MHz}, \mathrm{CD}_{3} \mathrm{OD}\right): \delta=8.72(\mathrm{~s}, 1 \mathrm{H}), 8.03(\mathrm{dd}, J=8.3,1.8 \mathrm{~Hz}, 1$ $\mathrm{H}), 7.67(\mathrm{~d}, J=8.3 \mathrm{~Hz}, 1 \mathrm{H}), 7.45-7.38(\mathrm{~m}, 2 \mathrm{H}), 7.31-7.23(\mathrm{~m}, 3 \mathrm{H}), 6.72$ (s, $1 \mathrm{H}), 5.25(\mathrm{~s}, 2 \mathrm{H}), 3.15-3.06(\mathrm{~m}, 8 \mathrm{H}), 2.78(\mathrm{~s}, 3 \mathrm{H}), 1.61-1.46(\mathrm{~m}, 8 \mathrm{H})$,
1.36-1.22 (m, $8 \mathrm{H}), 0.89$ (t, $J=7.4 \mathrm{~Hz}, 12 \mathrm{H}) \mathrm{ppm} .{ }^{13} \mathrm{C}-\mathrm{NMR}(101 \mathrm{MHz}$, $\left.\mathrm{CD}_{3} \mathrm{OD}\right): \delta=160.9,157.0,143.3,137.2,134.7,132.3,128.5,128.2,127.3$, 126.6, 125.8, 124.7, 122.9, 103.6, 77.2, 56.5, 23.8, 21.8, 17.7, 10.9 ppm. MS (ES-): $\mathrm{m} / \mathrm{z}(\%)=387.1\left(100,[\mathrm{M}]^{-}\right), 281.0\left(87,[\mathrm{M}-\mathrm{OBn}+\mathrm{H}]^{-}\right)$.

\section{2-Hydroxy-3-methylcarbamoyl-isoquinolin-1-one-7-sulfonic acid di- hydrate (6):}

Protected methyl amide $5(292 \mathrm{mg})$ was dissolved in a mixture of conc. $\mathrm{HCl}(3 \mathrm{~mL})$ and glacial HOAc $(3 \mathrm{~mL})$ and stirred at ambient temperature for $48 \mathrm{~h}$ and at $45^{\circ} \mathrm{C}$ for $12 \mathrm{~h}$. The solvents were removed under reduced pressure, the colorless oil was redissolved in a minimum of water, and applied onto a strongly acidic ion-exchange column (Dowex 50Wx2-400, $\mathrm{H}^{+}$form, activated with $8 \mathrm{wt} \% \mathrm{H}_{2} \mathrm{SO}_{4}$, elution with water). The fractions showing blue fluorescence on a Merck silica TLC plate $\mathrm{F}_{254}\left(\lambda_{\mathrm{ex}}=365 \mathrm{~nm}\right)$ were combined, concentrated, and dried under reduced pressure $(\mathrm{p} \approx 0.2$ mbar, $\left.\mathrm{T}_{\text {bath }}=35^{\circ} \mathrm{C}\right)$. The product was obtained as the dihydrate as a colorless solid ( $69 \mathrm{mg}, 30 \%$ over 2 steps).

${ }^{1} \mathrm{H}-\mathrm{NMR}\left(400 \mathrm{MHz}, \mathrm{CD}_{3} \mathrm{OD}\right): \delta=8.78(\mathrm{~s}, 1 \mathrm{H}), 8.11(\mathrm{~d}, J=8.3 \mathrm{~Hz}, 1 \mathrm{H})$, 7.78 (d, $J=8.3 \mathrm{~Hz}, 1 \mathrm{H}), 6.93$ (s, $1 \mathrm{H}), 2.94$ (s, $3 \mathrm{H}) \mathrm{ppm} .{ }^{13} \mathrm{C}-\mathrm{NMR}(101$ $\left.\mathrm{MHz}, \mathrm{CD}_{3} \mathrm{OD}\right): \delta=160.9,159.2,142.8,136.0,134.4,127.9,125.7,122.6$,

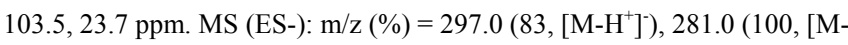
$\mathrm{H}^{+}$-O] $)^{-}$. Anal. Calcd. for $\mathrm{C}_{11} \mathrm{H}_{10} \mathrm{~N}_{2} \mathrm{O}_{6} \mathrm{~S} \bullet 2 \mathrm{H}_{2} \mathrm{O}\left(M_{\mathrm{r}}=334.30\right)$ : C, 39.52; $\mathrm{H}$, $4.22 ; \mathrm{N}, 8.38$. Found: C, 39.22; H, 4.37; N, 7.93 .

\section{Tetrabutylammonium 2-benzyloxy-3-chlorocarbonyl-isoquinolin-1-one} -7-sulfonate (7):

Under argon, the the protected carboxylate $4(51.0 \mathrm{mg}, 57.0 \mu \mathrm{mol}, 1.0$ equiv.) was dissolved in dry $\mathrm{CH}_{2} \mathrm{Cl}_{2}(2 \mathrm{~mL})$ and dry DMF $(2 \mathrm{mg})$ was added. Oxalyl chloride (36.2 mg, $285 \mu \mathrm{mol}, 5.0$ equivs.) was added dropwise and the yellow solution was heated under reflux for $3 \mathrm{~h}$. After cooling to ambient temperature, the volatiles were removed under reduced pressure and the remaining yellow solid (53 mg, quant.), that consisted of a 1:1 mixture of the title compound and tetrabutylammonium chloride, was dried in vacuo overnight (ca. 20 h). This material can be used without further purification.

${ }^{1} \mathrm{H}-\mathrm{NMR}(400 \mathrm{MHz}$, DMSO-d $\mathrm{d}$ ): $\delta=8.50(\mathrm{~s}, 1 \mathrm{H}), 7.94(\mathrm{dd}, J=8.3,1.2 \mathrm{~Hz}$, $1 \mathrm{H}), 7.79$ (d, $J=8.3 \mathrm{~Hz}, 1 \mathrm{H}), 7.54-7.46$ (m, $2 \mathrm{H}), 7.43-7.33$ (m, $3 \mathrm{H}), 7.12$ (s, $1 \mathrm{H}), 5.32(\mathrm{~s}, 2 \mathrm{H}), 3.23-3.00(\mathrm{~m}, 16 \mathrm{H}), 1.60-1.43(\mathrm{~m}, 16 \mathrm{H}), 1.25$ (sext., $J=7.2 \mathrm{~Hz}, 16 \mathrm{H}), 0.87$ (t, $J=7.2 \mathrm{~Hz}, 24 \mathrm{H}) \mathrm{ppm}$.

\section{X-ray crystallography of the disodium salt monohydrate of 3:}

Crystals were grown by slow evaporation of a solution of the title compound (prepared by addition of two equivalents of $\mathrm{NaOH}$ to 3 ) in $\mathrm{MeOH}$. A fragment of a colorless plate-like crystal of the title compound having approximate dimensions of $0.35 \times 0.11 \times 0.07 \mathrm{~mm}^{3}$ was mounted on a Kapton loop using Paratone $\mathrm{N}$ hydrocarbon oil. All measurements were made on a Siemens SMART $\mathrm{CCD}^{[14]}$ area detector with graphite monochromated Mo- $\mathrm{K}_{\alpha}$ radiation. Cell constants and an orientation matrix, obtained from a least-squares refinement using the measured positions of 2082 centered reflections with $\mathrm{I}>10 \sigma(\mathrm{I})$ in the range $2.32<\theta<26.36^{\circ}$ corresponded to a primitive monoclinic cell. The data were collected at a temperature of 142(2) K. Frames corresponding to an arbitrary hemisphere of data were collected using $\omega$ scans of $0.3^{\circ}$ counted for a total of 10 seconds per frame. Data were integrated by the program SAINT ${ }^{[15]}$ to a maximum $\theta$ value of $26.42^{\circ}$. The data were corrected for Lorentz and polarization effects. Data were analyzed for agreement and possible absorption using XPREP. ${ }^{[16]}$ An empirical absorption correction based on comparison of redundant and equivalent reflections was applied using SADABS $^{[17]}\left(\mathrm{T}_{\max }=0.95, \mathrm{~T}_{\min }=0.75\right)$. Of the 6939 reflections that were collected, 2514 were unique; equivalent reflections were merged. No decay correction was applied. The structure was solved within the Wingx ${ }^{[18]}$ package by direct methods (SIR92 ${ }^{[19]}$ ) and expanded using Fourier techniques (SHELXL-97 $7^{[20]}$ ). The aromatic hydrogen atoms were included 
but not refined. They were positioned geometrically, with $\mathrm{C}-\mathrm{H}=0.93 \AA$, and constrained to ride on their parent atoms. $\mathrm{U}_{\text {iso }}(\mathrm{H})$ values were set at 1.2 times $U_{e q}(C)$. The hydrogen atoms of the water molecule and the hydrogen between the carboxylate and the hydroxamate were located in the difference Fourier map and refined. $\mathrm{U}_{\text {iso }}(\mathrm{H})$ values were set at 1.2 times $\mathrm{U}_{\mathrm{eq}}(\mathrm{O})$.

\section{Acknowledgments}

The authors thank Michael D. Pluth for help with NMR spectra. M.S. thanks the German Research Foundation (DFG) for a research fellowship. This work was supported in part by NIH grant R01-HL69832 and by the Director, Office of Science, Office of Basic Energy Sciences, and the Division of Chemical Sciences, Geosciences, and Biosciences of the U.S. Department of Energy at LBNL under Contract No. DE-AC02-05CH11231.

[1] a) M. A. Santos, Coord. Chem. Rev. 2002, 228, 187-203; b) K. H. Thompson, C. A. Barta, C. Orvig Chem. Soc. Rev. 2006, 35, 545556 and refs cited therein.

[2] a) J. Rudinger, K. Poduska, M. Zaoral, Collect. Czech. Chem. Commun. 1960, 25, 2022-2028. b) R. L. N. Harris, Aust. J. Chem. 1976, 29, 1329-1334.

[3] a) J. R. Telford, K.N. Raymond, Siderophores in Comprehensive Supramolecular Chemistry, (Eds.: J. L. Atwood, J. E. D. Davies, D. D. MacNicol, F. Vögtle), Elsevier, Oxford, 1996, vol. 1, p. 245

[4] a) R. C. Hider, T. Zhou, Ann. N. Y. Acad. Sci. 2005, 1054, 141-154; b) Z. D. Liu, R. C. Hider, Med. Res. Rev. 2002, 22, 26-64; c) M Blanusa, V. M. Varnai, M. Piasek, K. Kostial, Curr. Med. Chem. 2005, 12, 2771-2294.

[5] a) R. A. Yokel, Coord. Chem. Rev. 2002, 228, 97-113; b) c) R. A. Yokel, P. Ackrill, E. Burgess, J. P. Day, J. L. Domingo, T. P. Flaten, J. Savory, J. Tox. Environ. Health 1996, 48, 667-683; d) P. Nayak, Environ. Res. Sect. A 2002, 89, 101-115.

[6] A. E. V. Gorden, J. Xu, K. N. Raymond, P. W. Durbin, Chem. Rev. 2003, 103, 4207-4282 and refs cited therein.

[7] a) E. J. Werner, S. Avedano, M. Botta, B. P. Hay, E. G. Moore, S. Aime, K. N. Raymond, J. Am. Chem. Soc. 2007, 129, 1870-1871; b) J. Xu, D. G. Churchill, M. Botta, K. N. Raymond, Inorg. Chem. 2004 , $43,5492-5494$.

[8] a) K. N. Raymond, R. C. Scarrow, D. L. White, patent US 796815 (1987); b) I. Turcot, A. Stintzi, J. Xu, K. N. Raymond J. Biol. Inorg. Chem. 2000, 5, 634-641.

[9] a) E. G. Moore, J. Xu, C. J. Jocher, E. J. Werner, K. N. Raymond J. Am. Chem. Soc. 2006, 128, 10648-10649; b) F. Gutierrez, C. Tedeschi, L. Maron, J.-P. Daudey, R. Poteau, J. Azema, P. Tisnès, C. Picard, Dalton Trans. 2004, 1334-1347.

[10] A. Du Moulinet d'Hardemare, S. Torelli, G. Serratrice, J.-L. Pierre, Biometals 2006, 19, 349-366 and refs. cited therein.

[11] a) M. Seitz, M. D. Pluth, K. N. Raymond, Inorg. Chem. 2007, 46, 351-353; b) M. Seitz, M.; A. G. Oliver, K. N. Raymond, J. Am. Chem. Soc. 2007, 129, 11153-11160.

[12] Crystal data for the disodium salt of 3: colorless plate, $\mathrm{C}_{10} \mathrm{H}_{5} \mathrm{NNa}_{2} \mathrm{O}_{7} \mathrm{~S} \bullet \mathrm{H}_{2} \mathrm{O}(347.21 \mathrm{~g} / \mathrm{mol})$, monoclinic, space group $\mathrm{P} 2_{1} / \mathrm{n}$ $\mathrm{a}=7.0552(6) \AA, \quad \mathrm{b}=17.0307(15) \AA, \quad \mathrm{c}=10.7581(10) \AA, \quad \alpha=\gamma=90^{\circ}$, $\beta=107.422(1)^{\circ}, V=1233.34(19) \AA^{3}, Z=4, T=142(2) \mathrm{K}, \lambda=0.71073 \AA$ $\rho_{\text {diff }}=1.87 \mathrm{~g} / \mathrm{cm}^{3}, \mu=0.377 \mathrm{~mm}^{-1}, \theta_{\max }=26.42^{\circ}$, meas. refls.: 6939 , indep. refls.: 2514 , refls. in refinement $(\mathrm{I}>2 \sigma(\mathrm{I}))$ : 1941 , parameters: 208, $\mathrm{R}\left(\mathrm{F}_{0}\right)=0.039, \mathrm{wR}\left(\mathrm{F}_{0}{ }^{2}\right)=0.095, \mathrm{GOF}=1.039$.

CCDC-664339 contains the supplementary crystallographic data for this paper. These data can be obtained free of charge from The Cambridge Crystallographic Data Centre via www.ccdc.cam.ac.uk/ data_request/cif.

Selected bond lengths $[\AA]$ and angles $\left[{ }^{\circ}\right]$ : N1-O2 = 1.393(2), N1-C1 $=1.365(3), \mathrm{C} 1-\mathrm{O} 1=1.240(3), \mathrm{C} 1-\mathrm{C} 2=1.461(3), \mathrm{C} 2-\mathrm{C} 7=1.410(3)$, $\mathrm{C} 2-\mathrm{C} 3=1.401(3), \mathrm{C} 3-\mathrm{C} 4=1.379(3), \mathrm{C} 4-\mathrm{S} 1=1.776(2), \mathrm{S} 1-\mathrm{O} 5=$ $1.460(2), \mathrm{S} 1-\mathrm{O} 6=1.456(2), \mathrm{S} 1-\mathrm{O} 7=1.452(2), \mathrm{C} 4-\mathrm{C} 5=1.402(3)$ $\mathrm{C} 5-\mathrm{C} 6=1.372(3), \mathrm{C} 6-\mathrm{C} 7=1.415(3), \mathrm{C} 7-\mathrm{C} 8=1.424(3), \mathrm{C} 8-\mathrm{C} 9=$
$1.356(3), \mathrm{C} 9-\mathrm{C} 10=1.512(3), \mathrm{C} 10-\mathrm{O} 3=1.285(3), \mathrm{C} 10-\mathrm{O} 4=$ $1.230(3), \mathrm{Na} 1-\mathrm{O} 1=2.304(2), \mathrm{Na} 1-\mathrm{O} 3=2.365(2), \mathrm{Na} 1-\mathrm{O} 4=$ $2.599(2), \mathrm{Na} 1-\mathrm{O} 6=2.378(2), \mathrm{Na} 1-\mathrm{O} 7=2.404(2), \mathrm{Na} 1-\mathrm{O} 8=$ $2.246(2), \mathrm{Na} 2-\mathrm{O} 1=2.450(2), \mathrm{Na} 2-\mathrm{O} 2=2.471(2), \mathrm{Na} 2-\mathrm{O} 4=$ $2.335(2), \mathrm{Na} 2-\mathrm{O} 5=2.420(2), \mathrm{Na} 2-\mathrm{O} 6=2.704(2), \mathrm{Na} 2-\mathrm{O} 7=$ $2.479(2)$; $\mathrm{C} 9-\mathrm{N} 1-\mathrm{O} 2=119.5(2), \mathrm{C} 1-\mathrm{N} 1-\mathrm{O} 2=114.7(2), \mathrm{N} 1-\mathrm{C} 1-\mathrm{O} 1$ $=119.9(2), \mathrm{C} 2-\mathrm{C} 1-\mathrm{O} 1=125.3(2)$.

[13] Ortep-3 for Windows: L. J. Farrugia, J. Appl. Crystallogr. 1997, 30, 565 .

[14] SMART (V5.059): Area-Detector Software Package, Bruker Analytical X-ray Systems, Inc.: Madison, WI, (1995-99).

[15] SAINT (V7.07B): SAX Area-Detector Integration Program; Siemens Industrial Automation, Inc.: Madison, WI, (2005).

[16] XPREP (V6.12): Part of the SHELXTL Crystal Structure Determination Package, Bruker AXS Inc.: Madison, WI, (1995).

[17] SADABS (V2.10): Siemens Area Detector ABSorption correction program, George Sheldrick, (2005).

[18] Wingx 1.70.01: L. J. Farrugia, J. Appl. Crystallogr. 1999, 32, 837838.

[19] SIR92: A. Altomare, G. Cascarano, C. Giacovazzo, A. Guagliardi, J. Appl. Crystallogr. 1993, 26, 343-350.

[20] SHELX97 - Programs for Crystal Structure Analysis (Release 97-2). Sheldrick, G.M., Institut für Anorganische Chemie der Universität Göttingen, Tammanstrasse 4, Göttingen, Germany, 1998. 